\title{
A carvedilolterápia előnyei magas cardiovascularis kockázatú betegek kezelése során
}

\author{
Fi Zsolt dr. - Szentes Veronika \\ Petz Aladár Megyei Oktató Kórház, Kardiológiai Osztály, Győr
}

\begin{abstract}
A kardiológiai gyógyszeres terápia eszköztárában a béta-blokkolók kiemelkedő helyen szerepelnek. Ennek több oka van. Egyrészt számos indikációs körrel rendelkeznek, annak ellenére, hogy a szakmai vezérfonalak a korábbiakhoz képest a társbetegséggel vagy szövődménnyel nem járó hypertonia kezelésében háttérbe szorították. Azonban a különböző kardiális szövődményekkel társuló hypertoniás esetek mellett az ischaemiás szívbetegség különböző klinikai megnyilvánulási formáiban (stabil angina pectoris, posztinfarktusos állapot), a szívelégtelenség és a szívritmuszavarok kezelésében alapvető szereppel bírnak. A gyógyszercsoport több évtizedes fejlődése során hemodinamikai hatásaik egyre kifinomultabbak lettek. Emellett nem szabad megfeledkeznünk arról sem, hogy újabb és újabb olyan tulajdonságokra derült fény, amelyek kedvezően befolyásolják a cardiovascularis betegségek kimenetelét. Ez utóbbi tulajdonságok igazolása számos multicentrikus tanulmányban rávilágított arra, hogy béta-blokkoló kezelés során miként érhető el a túlélésre kifejtett, a hemodinamikai hatástól is független kedvező effektus. Orv. Hetil., 2016, 157(26), $1029-1034$.
\end{abstract}

Kulcsszavak: béta-blokkolók, carvedilol, hypertonia, szívelégtelenség, oxidatív stressz, angina pectoris, diabetes mellitus

\section{The benefits of carvedilol therapy in the treatment of patients with high cardiovascular risk}

Among the variety of cardiologic pharmacological therapy options, beta-blockers stand on a prominent position. There are several reasons for this. On one hand they have numerous indication rounds, even though professional guidelines have recently tended to de-emphasize them for treatments of hypertension without complication or comorbidity. However, in addition to hypertonic cases associated with cardiac complication, they play a fundamental role in treating heart failure and arrhythmia and the different clinical manifestations (stable angina pectoris, myocardial state) of ischemic heart disease. The decade long development of the pharmacological group made its hemodynamic effects ever more refined. On the other hand we must not neglect the fact that more and more features came to light that positively influence the outcome of cardiovascular diseases. Verification of these latter features in numerous multicentric studies showed how to achieve a beneficial effect on survivability, independent on even hemodynamic effects during beta-blocker therapy.

Keywords: beta-blockers, carvedilol, hypertension, heart failure, oxidative stress, angina pectoris, diabetes mellitus

Fi, Zs., Szentes, $V$. [The benefits of carvedilol therapy in the treatment of patients with high cardiovascular risk]. Orv. Hetil., 2016, 157(26), 1029-1034.

(Beérkezett: 2016. április 8.; elfogadva: 2016. május 11.)

\section{Rövidítések}

$\mathrm{ACE}=$ angiotenzinkonvertáló enzim; $\mathrm{ARB}=$ angiotenzinreceptor-blokkoló; Ca-ATP-áz = kalcium-adenozin-trifoszfatáz; cAMP = cyclic adenosine monophosphate; CAPRICORN = Carvedilol Post-Infarct Survival Controlled Evaluation;
CLARIFY $=$ The prospeCtive observational LongitudinAl RegIstry oF patients with stable coronary arterY disease registry; COMET = Carvedilol Or Metoprolol European Trial; COPERNICUS $=$ Carvedilol Prospective Randomized Cumulative Survival; CRT-D = Cardiac resynchronization therapy 
device; GEMINI = The Glycemic Effect in Diabetes Mellitus = Carvedilol-Metoprolol Comparison in Hypertensives; LDL = low-density lipoprotein; MADIT-CRT = Multicenter Automatic Defibrillator Implantation Trial with Cardiac Resynchronization Therapy; MOCHA = Multicenter Oral Carvedilol in Heart Failure Assessment; Na-K-ATP-áz = nátrium-káliumadenozin-trifoszfatáz; NICE $=$ National Institute for Health and Care Excellence

\section{A béta-1-adrenoreceptor és a jelátvitel}

A kardiális sarcolemmán lévő béta-receptor az adrenerg jelátvitel során az adenil-cikláz enzim rendszerhez kapcsolódik. A G-protein teremti meg a kapcsolatot a receptor és az adenil-cikláz között. Gs-konfiguráció fennállása esetén létrejön a kapcsolat, Gi esetén viszont megszakad. Az adenil-cikláz hatására ATP-ből ciklikus AMP (cAMP) képződik. Az így képződött cAMP hatására megnyílnak a kalciumcsatornák. Ennek eredményeképp pozitív inotróp (a kontrakciót elósegító) effektus lép fel. A citoszolban lévő kalcium sarcoplasmás reticulumba történő viszszaáramlása fokozódik, amely izomelernyedést fokozó, vagyis pozitív luzitróp hatás létrejöttéhez vezet.

Ugyanez a mechanizmus a sinuscsomóban a frekvenciát fokozó, pozitív kronotróp hatáshoz vezet, az ingervezető rendszerben a vezetést elősegítő, pozitív dromotróp hatást eredményez.

Alapvetően béta-1-, illetve béta-2-receptort különíthetünk el. A béta-1-receptorok dominálóan a szívben találhatók, míg a béta-2-receptorok fóként a bronchusokban, illetve az erek simaizomzatában helyezkednek el. Az újabb béta-blokkolók alkalmazásával szelektív béta-blokkoló terápiára nyílik lehetőség, amelynek során a béta-2-hatáshoz köthető negatív pulmonológiai mellékhatások háttérbe szorulnak. Azonban béta-2-receptorok a szívizomban is előfordulnak, a gátló Gi-rendszerhez kapcsolódva gátlóhatást fejtenek ki, mérsékelve a bétal-izgalom aktiváló hatását, ezáltal egyensúlyt teremtve az egészséges szív adrenerg regulációjában $[1,2]$.

\section{A béta-blokkolók csoportjai}

A béta-blokkolók első generációjának képviselóje a propranolol, amely nem szelektív béta- 1 , illetve béta- 2 gátlása miatt fennáll a bronchospasmus veszélye. Ezeket a szereket ma már csak válogatott esetekben, hyperthyreosis, portalis hypertonia esetében alkalmazzuk.

A második generációs szerek csoportjába tartozik például az atenolol, metoprolol, bisoprolol. Ezek a készítmények kisebb dózisban viszonylag szelektíven hatnak a dominálóan a szívben található béta-1-receptorokra. És végül eljutottunk a harmadik generációhoz, amelynek tagjai additív értágító hatással rendelkeznek. Ennek a csoportnak két képviselójét kell kiemelnünk. Az egyik a nebivolol, amely amellett, hogy a jelenlegi legszelektívebb béta-blokkoló, a nitrogén-monoxid-képződést fo- kozó, vasodilatator hatással is bír. A másik, ebbe a csoportba tartozó szer a carvedilol, amely olyan nem szelektív béta-blokkoló, amely társuló alfa-blokkoló hatás révén okoz vasodilatatiót és antioxidáns hatással is rendelkezik [3].

\section{A cardiovascularis kockázat jelentősége a terápia meghatározásában}

A hypertonia a cardiovascularis megbetegedések kialakulásának egyik legfontosabb tényezője. A magasvérnyomás-betegség kezelésekor nem elegendő önmagában a vérnyomás csökkentése. Minden beteg esetében az öszszesített cardiovascularis kockázatot kell figyelembe vennünk a kezelés megtervezésekor. Az egyéni állapot felmérése során tisztázni kell, hogy fennállnak-e egyéb rizikófaktorok, amelyek közül legjelentősebbek a dohányzás, a lipid-, illetve szénhidrátanyagcsere-zavarok, amelyek a cardiovascularis rizikót alapvetően befolyásolják. Meglévő célszervkárosodás jelenléte (például igazolt szívizomnekrózis, coronariaszúkület, igazolt carotisérbetegség, lezajlott cerebrovascularis laesio, nephropathia) esetén vagy társuló anyagcsere-betegség (diabetes mellitus, metabolikus szindróma, hyperlipidaemia) fennállásakor pedig alapvetôen magas cardiovascularis rizikóról beszélünk [4]. A terápia tervezésekor természetesen nem hagyhatók figyelmen kívül olyan nem befolyásolható rizikótényező́k sem, mint például az életkor, nem és a genetikai tényezók. Egészen más megítélés alá esik egy fiatal, hypertoniás, más rizikófaktorokkal nem rendelkező nóbeteg vérnyomásának beállítása (természetesen esetleges szekunder hypertonia kizárása után), mint egy középkorú dohányzó, testsúlyfelesleggel bíró férfi beteg kezelése, akinek pozitív családi anamnézis is szerepel a kórelőzményében. Míg előbbi esetben a kezelés megkezdésekor akár életmódbeli tényezők betartása, ennek sikertelensége esetén monoterápia is elegendő lehet a kívánatos vérnyomásértékek eléréséhez, utóbbi esetben már kombinációs kezelésre van szükség.

A 2011-es NICE Guideline-ban megfogalmazott új hypertonia-irányelvek szerint, amelyek a korábbiakhoz képest jelentôs változásokat hoztak a magas vérnyomás ajánlott kezelési sémájában [5], elsőként választandó szerként az angiotenzinkonvertálóenzim- (ACE-) inhibitorok jönnek szóba. Intolerancia esetén angiotenzinreceptor-blokkoló (ARB) készítmények javasoltak [6]. Már ennek szellemében született meg 2015-ben a legújabb hazai hypertoniaajánlás is [7].

Mindent egybevetve azonban, igazolt balkamra-diszfunkció, manifeszt szívelégtelenség, ischaemiás szívbetegség és posztinfarktusos állapot esetén elkerülhetetlen a béta-blokkolók alkalmazása.

Az első generációs béta-blokkolókat már csak speciális helyzetekben használjuk, általában pajzsmirigy-túlmüködés és májcirrózis szövődményeként kialakult portalis hypertonia eseteiben. A második generációs, szelektív béta-blokkolók még ma is széleskörúen használtak, évti- 
zedeken keresztül bizonyították hatásosságukat, számos nagy tanulmány igazolta a szív- és érrendszeri betegségekben a mortalitásra és a cardiovascularis kemény végpontokra kifejtett kedvező hatásukat. Azonban nem szabad megfeledkeznünk arról, hogy ezek a szerek, fóként a metoprolol, nagyobb dózisban alkalmazva már kevésbé kardioszelektívek és az anyagcserehatásuk is kedvezőtlen. Azt lehetne elemezni, hogy az alkalmazásukkal nyert haszon vajon ellensúlyozza-e a kezelés veszélyeit, de ez a kérdés a harmadik generációs béta-blokkolók alkalmazásával értelmetlenné vált. Ugyanis utóbbi csoportba tartozó szerek már nem rendelkeznek ilyen kedvezőtlen tulajdonságokkal. Az ebbe a csoportba tartozó carvedilol és nebivolol az értágító, illetve egyéb pleiotróp hatásaik által nem csupán a megbízható vérnyomáscsökkentés, a 24 órás hatástartam, hanem a centrálisvérnyomás-csökkentés révén biztosított cardiovascularismortalitás-csökkentés, illetve az anyagcserehatások irányában mutatott semlegesség okán is a béta-blokkoló kezelés élvonalába helyezik ezeket a szereket $[3,8,9]$. Fontos kiemelnünk, hogy a carvedilol indikációs köre jelenleg szélesebb a nebivololnál, mivel utóbbi essentialis hypertonia mellett stabil, enyhe, illetve középsúlyos krónikus szívelégtelenség kezelésének kiegészítésére alkalmazható időskorú (70 éves és idősebb) betegeknél. Ezzel szemben a carvedilol posztinfarktusos állapotokban, mind hypertonia, mind pedig balkamra-diszfunkció, illetve manifeszt szívelégtelenség esetén is alkalmazható.

\section{A carvedilol egyedi hatásmechanizmusa}

\section{Hemodinamikai hatások}

A béta-blokkolók többségének hatására a coronariaerek szintjén vasoconstrictio jön létre, azonban carvedilol esetén nem kell számolnunk ezzel a hatással. A csökkenő szívfrekvencia hatására nő a diasztolés telődés, javul a szívizom oxigén- és energiaellátása [8].

A hagyományos béta-blokkolók elsősorban a szívfrekvencia és az inotrópia csökkentésével a szív teljesítményének csökkentésével vezetnek vérnyomáscsökkenéshez. Alkalmazásuk esetén először a csökkenő perctérfogat hatására átmenetileg nő a perifériásér-ellenállás, majd utóbbi enyhülésével alakul ki a valós vérnyomáscsökkentő hatás.

A carvedilol a béta-receptorok mellett az $\alpha \mathrm{l}$-adrenoreceptorokat is blokkolja, ami a perifériás erek vasodilatatiójához vezet, csökkentve a szisztémás vascularis rezisztenciát és ezáltal a vérnyomást. Nagy dózisban enyhe kalciumantagonista tulajdonságokkal is bír $[8,10,11]$.

A harmadik generációs béta-blokkolók vasodilatativ tulajdonsága révén a perctérfogat csökkenése nélkül alakulhat ki megfelelő vérnyomáscsökkentő effektus. A vérnyomáscsökkentő hatáshoz hozzájárul még a praejunctionalis béta-receptorok gátlása, illetve a reninkiáramlás gátlása révén csökken a renin-angiotenzin rendszer aktivitása is [10].
Rövid távon a béta-blokkoló kezelés csökkenti a vérnyomást, illetve a szív inotrópiáját, hosszú távon azonban javítják a szívmúk ödést, nő az ejekciós frakció, csökken a bal kamrai végdiasztolés nyomás, illetve visszafordítják a bal kamrai remodelling folyamatát javuló hemodinamikai státuszt eredményezve. Emellett jótékony hatásuk a szívfrekvencia csökkentésében, illetve a kamrai arrhythmiák rizikójának csökkentésében is megnyilvánul [11].

Szívelégtelenségben a fokozott adrenerg aktivitás hatására a szívizom béta-1-receptorok sejtfelszíni számának csökkenése, „down-regulációja” jön létre, védőmechanizmusként csökken a szimpatikus hatás kontrakciót okozó hatása. A béta-2-receptorok „down-regulációja” kisebb mértékü, ezért számuk relatíve nő, a béta-2-hatás fennmaradása pedig gátolja az apoptózist. A béta-blokkolók hatására nô a béta-receptorok száma, amelynek következtében javul a szisztolés funkció $[8,10]$.

A carvedilolkezelés kevesebb kezdeti hemodinamikai problémával jár, mivel a cardiac output megtartott marad, sőt enyhén emelkedhet a vasodilatator komponens miatt. Mivel a carvedilol a béta-2-, illetve alfa-1-receptorokat is blokkolja, csökkenti a kardiális adrenerg aktivitást, illetve megakadályozza a béta-receptorok „upregulációját”, a béta-adrenerg-jelátvitel helyreállítását, ezáltal komplex jótékony antiadrenerg hatást biztosít a károsodott szívben [12].

\section{Az oxidativ stressz}

Normális körülmények között a szabadgyök-megkötők múködése és a szabadgyök-termelődés egyensúlyban van. Krónikus szívelégtelenségben utóbbiak meghaladják a szabadgyök-fogók (szuperoxid dizmutáz, glutation peroxidáz és kataláz) produkcióját, ami fokozott oxidatív stresszhez vezet. Szívelégtelenségben a szívizom-anyagcsere károsodása során fellépő oxidatív stressz hozzájárul a kontraktilitási zavar, illetve a kamrai remodelling kifejlődéséhez. Mindez kedvez a malignus ritmuszavarok kialakulásának, illetve a hirtelen szívhalál fellépésének.

A sarcoplasmás reticulum Na-K-adenozin-trifoszfatáz (Na-K-ATP-áz) és a Ca-adenozin-trifoszfatáz (Ca-ATP-áz) aktivitása károsodik, ami a kalciumion sarcolemmán keresztüli áramlásának megváltozásához vezet. Az emelkedett intracelluláris kalciumszint kontraktilitási zavar kialakulásához vezethet [13].

A carvedilol erélyes antioxidáns hatással bír, ami a benne lévő carbazolmolekula-résznek köszönhető. Humán izolált pitvari és kamrai myocardiumban a hidroxi-szabadgyökök csökkentik a kontrakciós erőt, nő a diasztolés feszülés és csökken a külső kalciumra adott inotróp válaszkészség, gátlódik a sarcoplasmaticus reticulum Ca-ATP-áz-aktivitása. Mind a carvedilol, mind metabolitja, a BM-910228 helyreállítja az inotróp válaszkészséget hidroxi-szabadgyökökkel kezelt myocardiumban. Elmondhatjuk, hogy a carvedilol és metabolitjai több 
más hatásuk mellett a szabadgyök-károsodás megelőzése által hasznosak krónikus szívelégtelenségben [13, 14].

Szívizom-ischaemia fennállása esetén a carvedilol, hasonlóan a többi béta-blokkolóhoz, a szívfrekvencia és inotrópia csökkentése révén mérsékli az oxigénigényt. Alfa-blokkoló hatásából adódóan perifériás vasodilatatio révén csökkenti a szív utóterhelését. Ezeket a hemodinamikai hatásokat antioxidáns hatás egészíti ki. Szívizomischaemia, következményes reperfúzió okozta szívizomkárosodásban az antioxidáns hatás, illetve az adrenoreceptor-blokád magyarázhatja a többi béta-blokkolóval szemben mutatott előnyeit szívizom-ischaemiás, reperfúziós állatmodellekben. Összességében elmondható, hogy több mechanizmus együttese, az adrenoreceptor-blokád, alfa-blokkoló hatásból adódó vasodilatatio, illetve antioxidáns effektus magyarázhatja hatásosságát ischaemiás szívizom-károsodás esetén [12].

Az LDL (low-density lipoprotein) oxidációja jelentős szerepet játszik az atherosclerosis kialakulásában. A carvedilol gátolja az LDL-molekula oxidációját hypertoniás egyénekben. Ez az LDL-szint-csökkenés független a vérnyomás változásától [15].

\section{Carvedilolterápia indikációi}

\section{Essentialis hypertonia}

A guideline mindenkori figyelembevétele mellett a klinikai gyakorlatban, ha szükséges, akkor olyan béta-blokkolót célszerú választani, amely a nagy betegszámot felölelő tanulmányok és saját klinikai tapasztalataink alapján az egyik legmodernebb készítménynek tartható, illetve az egyik legszélesebb törzskönyvi indikációs spektrummal rendelkezik. A béta-blokkolók közül ezeknek a feltételeknek jelenleg a carvedilol felel meg. Modern bétablokkoló tulajdonságait az előzőekben részleteztük.

Alkalmazásakor nem kell számolnunk káros anyagcserehatásokkal. Ez egyaránt lehetővé teszi alkalmazásukat fiatal, kisebb cardiovascularis rizikójú hypertoniás betegekben, valamint magas cardiovascularis rizikójú egyéneknél is. Utóbbi betegcsoportban már meglévő lipid- és szénhidrátanyagcsere-zavar esetén az antihipertenzív terápia része lehet anélkül, hogy a metabolikus paraméterek romlásával kellene számolnunk.

A GEMINI vizsgálatban carvedilol és metoprolol hatását hasonlították össze hypertoniás, diabeteses betegekben. Míg a két szerrel hasonló vérnyomáscsökkenés volt elérhető, addig a carvedilolnak sokkal kedvezőbb anyagcserehatásai voltak $[8,10,16]$.

\section{Szivelégtelenség}

A következő és talán legfontosabb indikációs terület a szívelégtelenség. A béta-blokkolóknak a szívelégtelenség kezelésében a mortalitásra, mint kemény végpontra kifejtett kedvező hatását számos tanulmány bizonyította. Carvedilol esetén sincs ez másképp, sőt a béta-blokko- lóknak a szívelégtelenség kezelésében betöltött kedvező hatásait illetően a carvedilol az egyik legjobban dokumentált készítmény [10]. Fontos kiemelnünk, hogy a carvedilol az egyetlen béta-blokkoló, amely már kis dózisban is mortalitáscsökkentő hatással bír.

Az US Carvedilol Heart Failure Study Group eredményeit vizsgálva a standard (ACE-inhibitort is tartalmazó) terápiához adott carvedilol gátolja a klinikai progressziót enyhe tüneteket mutató jól kompenzált szívelégtelenség esetén [17]. A MOCHA vizsgálat igazolta, hogy enyhe és középsúlyos szisztolés szívelégtelenségben a carvedilol dózisfüggő balkamra-funkció-javulást hoz létre, illetve dózisfüggően csökkenti a mortalitást, valamint a hospitalizációs gyakoriságot [12].

A COPERNICUS (Carvedilol Prospective Randomized Cumulative Survival) vizsgálatban nyugalomban vagy minimális terhelésre a szívelégtelenség tüneteit mutató, jelentősen csökkent balkamra-funkciójú betegekben $(\mathrm{EF}<25 \%)$ vizsgálták a carvedilol hatékonyságát. A vizsgálat eredménye alapján $35 \%$-kal csökkent a mortalitás, a halálozás és a szívelégtelenség miatt szükséges hospitalizáció rizikója is 31\%-kal [18].

A COMET vizsgálatban a carvedilol 33\%-kal kedvezőbbnek bizonyult az összhalálozás tekintetében a metoprolol-tartarátnál krónikus szívelégtelenségben.

A MADIT-CRT tanulmányban a carvedilolt metoprolollal hasonlították össze tünetszegény, de alacsony ejekciós frakciójú szívelégtelen betegek eszközös terápiája mellett. A carvedilollal kezelt betegekben szignifikáns mértékben alacsonyabb volt a hospitalizációs gyakoriság, illetve a halálozás. A kockázatcsökkenés még kifejezettebb volt a kardiális reszinkronizációs kezelést kapó, illetve a CRT-D készülékkel kezelt bal-Tawara-szár-blokkos betegek esetén. A carvedilolcsoportban a malignus ritmuszavarok is ritkábban fordultak elö [19].

Mindezek alapján a carvedilol a szívelégtelenség minden stádiumában javasolt béta-blokkoló készítmény.

\section{Krónikus stabil angina pectoris, posztinfarktusos állapot}

Az ischaemiás szívbetegség kezelése során a carvedilol szintén számos evidenciával rendelkezik. Indikációs köre kiterjed a krónikus stabil angina pectoris tartós kezelésére, illetve az akut myocardialis infarctust követően kialakult balkamra-diszfunkcióra is. Utóbbi során egyedülállónak tartható, hogy mindehhez anyagcsere-semlegesség társul. A CAPRICORN vizsgálatban (Carvedilol PostInfarct Survival Controlled Evaluation) carvedilol hatását vizsgálták akut myocardialis infarctuson átesett, csökkent balkamra-funkciójú (ejekciós frakció <40\%) betegekben. A vizsgálat során a carvedilol szignifikánsan, 23\%-kal csökkentette az összmortalitást. A vizsgálat echokardiográfiás alcsoportjában a myocardialis infarctuson átesett balkamra-diszfunkciós betegeknél szignifikánsan javult az ejekciós frakció $[20,21]$. 
Összességében a készítmény a cardiovascularis betegségek széles spektrumában alkalmazható anélkül, hogy káros anyagcserehatásokkal kellene számolnunk.

\section{Carvedilol alkalmazása a mindennapi gyakorlatban}

A hypertoniás betegpopuláció közel negyedében diabetes mellitus fennállásával is kell számolnunk. A két betegség együttes jelenléte jelentős mértékben megemeli a cardiovascularis kockázatot. Ebben a betegcsoportban a megfelelő antihipertenzív hatás eléréséhez gyakran gyógyszer-kombinációk alkalmazására van szükség. A kombinációs terápia alapvető eleme - amennyiben ellenjavallat, illetve intolerancia nem áll fenn - az angiotenzinkonvertálóenzim-inhibitor gyógyszercsoport, amennyiben utóbbi nem adható, akkor az angiotenzinreceptor-blokkolók adása javasolt. Abban az esetben, ha kardiológiai betegség is fennáll (stabil vagy instabil koszorúér-betegség, akut coronariaszindróma, myocardialis infarctus vagy azt követô állapot, különböző etiológiájú szívelégtelenség) szinte elkerülhetetlen bétablokkolók alkalmazása. Ma már a semleges vagy kedvező anyagcsere hatású 3. generációs készítmény, az előbbiekben felsorolt cardiovascularis indikációkban bizonyított hatásosságú carvedilol alkalmazása javasolt.

Jelenleg a béta-blokkoló felírási gyakorlata hazánkban elsősorban háziorvosi, de szakorvosi szinten sem követi kellő mértékben a szakmai ajánlásokat. Szentes és mtsai közelmúltban elvégzett vizsgálata alapján a háziorvosok és szakorvosok között is a bisoprolol a leggyakrabban alkalmazott béta-blokkoló. Háziorvosok esetében a diabeteses hypertoniás betegek körében a metoprolol, a nebivolol és a carvedilol felírási gyakorisága csaknem azonos. Ezzel szemben a szakorvosok fele annyi metoprololt javasolnak betegeiknek, mint nebivololt és bisoprololt, ugyanakkor még mindig alig részesítik előnyben a carvedilolt a metoprolollal szemben [22]. Sok esetben tapasztaljuk a gyakorlatban, hogy a kórházi ellátásra szoruló beteg a hospitalizációt megelőzően pusztán a magasvérnyomás-betegség kezelésére metoprololt szedett, ráadásul sokszor rövid hatású aluldozírozott készítményt. Pedig jól tudjuk, hogy ezek a hatóanyagok éppen kedvezőtlen anyagcsereprofiljuk miatt kerültek ki ma már az antihipertenzív terápia eszköztárából [5]. El kell érnünk azt, hogy a diabeteses, hypertoniás beteg mind az alapellátás, mind a szakorvosi ellátás szintjén anyagcsere-semleges készítményt kapjon, amely a gyakorlatban a carvedilol, illetve nebivolol alkalmazását jelenti, figyelembe véve az utóbbi szúk indikációs spektrumát. Ennek ellenére a betegek közel 40-47\%-a az anyagcsere szempontjából kedvezőtlenebb hatású metoprolol, illetve bisoprolol készítményt kapja [22].

A beteg gyakran a kórházi kezelés során vagy a szakrendelőben elindított, majd a továbbiakban nem kellően titrált béta-blokkoló kis dózisát kapja, amely nem kizárólag hazai jelenség. Ezt a tendenciát igazolta a stabil coro- nariabetegek körében végzett nemzetközi CLARIFY (The prospeCtive observational LongitudinAl RegIstry oF patients with stable coronary arterY disease registry) vizsgálat összesítése is. Annak ellenére nem emelték a béta-blokkolók dózisát a célfrekvencia eléréséig, hogy ezeknek a betegeknek szignifikánsan gyakrabban jelentkeztek anginái és ischaemiával kísért klinikai eseményei [23]. Pedig a cél a tanulmányokban hatásosnak ítélt tolerálható maximális dózis elérése kell legyen. A carvedilol számos hatáserőssége révén jól titrálható, kiszámítható hatású készítmény, amely a szer egyik fó erőssége a mindennapi használat során.

\section{Következtetés}

Elmondhatjuk, hogy a cardiovascularis betegségek esetén a megfelelő béta-blokkoló meghatározása során gyakrabban kell gondolnunk a carvedilolra, mivel ezáltal olyan készítményt alkalmazunk, amely kellő számú evidenciával bizonyította hatásosságát a szív- és érrendszeri betegségek széles skáláján. Mindemellett jól tolerálható, biztonságos, és ami talán a legfontosabb: anyagcserehatások szempontjából előnyös béta-blokkolót adhatunk betegeinknek.

Anyagi támogatás: A közlemény megírása anyagi támogatásban nem részesült.

Szerzői munkamegosztás: A szerzők egyenlő arányban járultak hozzá a közlemény megírásához. A cikk végleges változatát elolvasták és jóváhagyták.

Érdekeltségek: A szerzőknek nincsenek érdekeltségeik.

\section{Irodalom}

[1] Zamah, A. M., Delahunty, M., Luttrell, L. M., et al.: Protein kinase A-mediated phosphorylation of the beta 2 -adrenergic receptor regulates its coupling to Gs and Gi. Demonstration in a reconstituted system. J. Biol. Chem., 2002, 277(34), 3124931256.

[2] Mason, D. A., Moore, J. D., Green, S. A., et al.: A gain-of-function polymorphism in a G-protein coupling domain of the human betal-adrenergic receptor. J. Biol. Chem., 1999, 274(18), 12670-12674.

[3] Dézsi, C. A.: On what criteria should we choose the beta-blocker? [Mi alapján válasszunk béta-blokkolót?] Card. Hung., 2012, 42(5), 317-321. [Hungarian]

[4] Dézsi, C. A.: The role of $\beta$-blockers in patients with metabolic syndrome and hypertension. [A $\beta$-blokkolók helye a metabolikus szindrómás hypertoniás betegek kezelésében.] Orv. Hetil., 2015, 156(16), 623-625. [Hungarian]

[5] Dézsi, C. A.: The most important components of the 2011 NICE Guideline. [A 2011-es NICE Guideline legfontosabb elemei.] Háziorvos Továbbképző Szemle, 2012, 17(2), 84-87. [Hungarian]

[6] Dézsi, C. A.: The different therapeutic choices with ARBs. Which one to give? When? Why? Am. J. Cardiovasc. Drugs, 2016 Mar 3. [Epub ahead of print] DOI: 10.1007/s40256-016-0165-4 
[7] Kiss, I. (ed.): Treatment of hypertension disease. Professional guideline of the Hungarian Hypertension Society. [A hypertoniabetegség ellátása. A Magyar Hypertonia Társaság szakmai irányelve.] Hypertonia és Nephrologia, 2015, 19(Suppl. 1), 1-38. [Hungarian]

[8] Simonyi, G.: Beta-blockers in practice - the metabolically neutral carvedilol in focus. [A béta-blokkolók a gyakorlatban - Fókuszban a metabolikusan semleges carvedilol.] Card. Hung., 2013, 43(3), 127-131. [Hungarian]

[9] Moser, Gy., Dézsi, C. A.: Problems and solutions in switching from a selective $\beta$-blocker to carvedilol. [Problémák és megoldások szelektív béta-blokkolóról carvedilolra történő terápiaváltás kapcsán.] Card. Hung., 2006, 36(4), 283-288. [Hungarian]

[10] DiNicolantonio, J. J., Fares, H., Niazi, A. K., et al.: $\beta$-blockers in hypertension, diabetes, heart failure and acute myocardial infarction: a review of the literature. Open Heart, 2015, 2(1), $\mathrm{e} 000230$.

[11] Abdel-Razek, T. T., Bennasir, H., Sridhar, S., et al.: Carvedilol - a novel "look" at $\beta$-blockers in management of cardiovascular disease. Int. J. Pharma Bio Sci., 2010, 1(2), 12.

[12] Bristow, M. R., Gilbert, E. M., Abrabam, W. T., et al.: Carvedilol produces dose-related improvements in left ventricular function and survival in subjects with chronic heart failure. Circulation, 1996, 94(11), 2807-2816.

[13] Book, W. M.: Carvedilol: A nonselective $\beta$ blocking agent with antioxidant properties. Congest. Heart Fail., 2002, 8(3), 173177., 190

[14] Flesch, M., Maack, C., Cremers, B., et al.: Effect of $\beta$-blockers on free radical-induced cardiac contractile dysfunction. Circulation, 1999, 100(4), 346-353.

[15] Maggi, E., Marchesi, E., Covini, D., et al.: Protective effects of carvedilol, a vasodilating $\beta$-adrenoreceptor blocker, against in vivo low density lipoprotein oxidation in essential hypertension. J. Cardiovasc. Pharmacol., 1996, 27(4), 532-538.

[16] Bakris, G. L., Fonseca, V., Katholi, R. E., et al.: Metabolic effects of carvedilol vs. metoprolol in patients with type 2 diabetes mel- litus and hypertension: a randomized controlled trial. JAMA, 2004, 292(18), 2227-2236.

[17] Colucci, W. S., Packer, M., Bristow, M. R., et al.: Carvedilol inhibits clinical progression in patients with mild symptoms of heart failure. Circulation, 1996, 94(11), 2800-2806.

[18] Packer, M., Fowler, M. B., Roecker, E. B., et al.: Effect of carvedilol on the morbidity of patients with severe chronic heart failure: results of the carvedilol prospective randomized cumulative survival (COPERNICUS) study. Circulation, 2002, 106(17), 2194-2199.

[19] Ruwald, M. H., Ruwald, A. C., Jons, C., et al.: Effect of metoprolol versus carvedilol on outcomes in MADIT-CRT (Multicenter automatic defibrillator implantation trial with cardiac resynchronization therapy). J. Am. Coll. Cardiol., 2013, 61(14), 1518-1526.

[20] Doughty, R. N., Whalley, G. A., Walsh, H. A., et al.: Effects of carvedilol on left ventricular remodeling after acute myocardial infarction: the CAPRICORN Echo Substudy. Circulation, 2004, 109(2), 201-206.

[21] Dargie, H. J.: Effect of carvedilol on outcome after myocardial infarction in patients with left-ventricular dysfunction: the CAPRICORN randomised trial. Lancet, 2001, 357(9266), $1385-1390$.

[22] Szentes, V., Kovács, G., Dézsi, C. A.: Domestic practice of antihypertensive treatment of diabetic hypertensive patients. [Diabeteses hypertoniás betegek vérnyomáscsökkentő kezelésének hazai gyakorlata.] Orv. Hetil., 2014, 155(43), 1695-1700. [Hungarian]

[23] Steg, P. G., Ferrari, R., Ford, I., et al.: Heart rate and use of betablockers in stable outpatients with coronary artery disease. PLoS ONE, 2012, 7(5), e36284.

(Fi Zsolt dr.,

Györ, Vasvári Pál út 2-4., 9024 e-mail: fizsolt33@gmail.com)

A cikkben szereplő adatok és információk a szerző nézeteit tükrözik.

Bármely említett termék alkalmazásakor az érvényes alkalmazási előirat az irányadó. 